\title{
Educational inequalities in cancer survival: a role for comorbidities and health behaviours?
}

\author{
Mieke J Aarts, ${ }^{1}$ Carlijn B M Kamphuis, ${ }^{2}$ Marieke J Louwman, ${ }^{1}$ \\ Jan Willem W Coebergh, ${ }^{1,2}$ Johan P Mackenbach, ${ }^{2}$ Frank J van Lenthe ${ }^{2}$
}

- Additional supplementary tables are published online only. To view these files please visit the journal online (http:// dx.doi.org/10.1136/jech-2012201404)

${ }^{1}$ Comprehensive Cancer Centre South, Eindhoven Cancer Registry, Eindhoven, The Netherlands

${ }^{2}$ Department of Public Health, Erasmus University Medical

Centre, Rotterdam,

The Netherlands

\section{Correspondence to}

Mieke J Aarts,

Comprehensive Cancer Centre South, Eindhoven Cancer Registry, P.O. Box 231, Eindhoven $5600 \mathrm{AE}$

The Netherlands; research@ikz.nl

Received 18 April 2012 Revised 31 October 2012 Accepted 7 November 2012 Published Online First 8 December 2012

\footnotetext{
To cite: Aarts MJ, Kamphuis CBM, Louwman MJ, et al. J Epidemiol Community Health 2013;67:365-373.
}

\section{ABSTRACT}

Aim To describe educational inequalities in cancer survival and to what extent these can be explained by comorbidity and health behaviours (smoking, physical activity and alcohol consumption).

Methods The GLOBE study sent postal questionnaires to individuals in The Netherlands in 1991 resulting in 18973 respondents (response 70\%). Questions were asked on education, health and health-related behaviours. Participants were linked for cancer diagnosis (1991-2008), comorbidity and survival (up to 2010) with the population-based Eindhoven Cancer Registry; 1127 tumours were included in the analyses.

Results 5-year crude survival was best in highly educated patients as compared with low educated patients for all cancers combined: $49 \%$ versus $32 \%$ in male subjects (log rank: $p<0.0001), 65 \%$ versus $49 \%$ in female subjects ( $p=0.0001)$. Compared with highly educated, low educated prostate cancer patients had an increased risk of death (HR $2.9(95 \% \mathrm{Cl} 1.7$ to 5.1$)$, adjusted for age, stage and year). No or inconsistent associations between educational level and risk of death were seen in multivariable analyses for breast, colon and non-small cell lung cancer. Although survival in prostate cancer patients was affected by comorbidities

(HR 2_vs_0_comorbidities: 2.6 (1.5 to 4.4)), physical activity

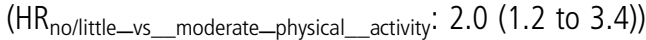
and smoking (HR $\mathrm{HR}_{\text {current-vs_never_smokers: }} 2.6$ (1.0-6.8)), these did not contribute to educational inequalities in prostate cancer survival ( $\mathrm{HR}_{\text {low_vs_high_education: }} 3.1$ (1.6 to 5.8) with adjustment for comorbidity and lifestyle). Conclusions Compared with low educated, highly educated prostate cancer patients had better survival. Although presence of comorbidities, physical activity levels and smoking status affected survival from prostate cancer, these did not contribute to educational inequalities in survival. The role of other factors for inequalities in cancer survival needs to be explored.

\section{INTRODUCTION}

Many studies report the highest cancer mortality rates among those with low socioeconomic position (SEP). ${ }^{1-4}$ This disadvantage may be the result of higher cancer incidence in low SEP groups. Indeed, people from lower socioeconomic strata have more or less consistent excess risks for respiratory cancers, cancers of the head and neck and upper gastrointestinal tract, liver and cervix uteri. ${ }^{1}{ }^{5-7}$ Risks for cancers of the colon, breast and ovary and malignant melanoma are generally lower in those with a low SEP, ${ }^{15-7}$ which are likely related to socioeconomic differences in unhealthy behaviours. Part of the increased risks of developing lung and breast cancer can be explained by smoking, alcohol intake and physical activity. ${ }^{8}$ Recently, smoking was thought to explain 19\% of all new cancer cases in the UK, whereas deficient intake of fruits and vegetables, occupational exposures, overweight and obesity and infectious agents explained $4 \%-7 \%$ of cancer incidence. ${ }^{9}$

Increased cancer mortality rates among people with lower SEP may result from increased incidence and poorer survival from cancer. Survival rates from cancer are generally better for patients with high $\mathrm{SEP}^{4} 5$ 10-12 which has been ascribed partly to lower prevalence of other chronic diseases (comorbidities) in high SEP cancer patients. ${ }^{13}{ }^{14}$ The presence of these comorbidities is affected by lifestyle (eg, smoking is related to the occurrence of chronic obstructive pulmonary disease (COPD) and cardiovascular disease), and lifestyle likely influences the socioeconomic inequalities in cancer survival as well. Because unhealthy behaviours are not necessarily reflected in quantifiable comorbidity scores, lifestyle may further explain socioeconomic inequalities in cancer survival. Previous studies on this topic reported small effects of smoking, physical activity and alcohol consumption upon socioeconomic differences in survival from respiratory-related cancers, colorectal cancers and all cancers combined in New Zealand and Sweden. ${ }^{15} 16$ The explanatory role of lifestyle in socioeconomic inequalities in cancer survival has not been studied for other cancers separately nor the additional effect of comorbidities. The aim of our study is to describe educational inequalities in cancer survival and to what extent these inequalities can be explained by comorbidity and lifestyle factors.

The prospective GLOBE study was designed to investigate several explanations for socioeconomic inequalities in health in The Netherlands. Linkage of information from study participants to the Eindhoven Cancer Registry enabled us to study the presence of socioeconomic inequalities in cancer survival and the contribution of three cancer-related behavioural risk factors (alcohol consumption, smoking and physical activity) and comorbidities.

\section{METHODS \\ Population}

The prospective cohort, that is, the Dutch GLOBE study, started in 1991, and aimed to investigate the contribution of explanatory factors to socioeconomic inequalities in health. GLOBE is the Dutch acronym for 'Health and Living Conditions of the Population of Eindhoven and Surroundings'. A detailed description of the purpose and design of the GLOBE study, and the main results after the first 10 years are presented elsewhere. ${ }^{17}{ }^{18}$ In short, 
in 1991 a postal questionnaire was sent to non-institutionalised Dutch persons between 15 and 75 years of age, living in or near the city of Eindhoven, to which 18973 individuals responded (70.1\%). The questionnaire included measures of SEP, selfreported health, health-related behaviour (eg, smoking, alcohol consumption, physical activity), material circumstances (housing, income), psychosocial characteristics (marital status, vitality), healthcare utilisation and childhood circumstances.

\section{Cancer survival}

The population-based Eindhoven Cancer Registry has collected data on new cancer patients since 1955 according to international guidelines. ${ }^{19}$ Trained registry personnel actively collects data on diagnosis, staging and treatment. Stage was divided according to Tumour Node Metastasis (TNM) classification at the year of diagnosis, according to the fourth, fifth and sixth International Union Against Cancer editions, as appropriate. ${ }^{20-}$ 22 Pathological T, N and M stages were used; clinical stage was used if pathological stage was missing. In prostate cancer, we used the clinical stage. Clinical TNM stage was determined by physical examination, imaging, endoscopy, biopsy, surgical exploration and other relevant examinations. Pathological TNM stage was based on the evidence acquired before treatment, supplemented or modified by the additional evidence acquired from surgery and from pathological examination.

The registry also records serious comorbidity at diagnosis according to an adaptation of the list of Charlson and coworkers. $^{23}$ An overview of the comorbidities associated with the various cancer sites in relation to SEP is given elsewhere. ${ }^{13}$

Since 1988, the registry has covered an area in the south-east of The Netherlands with a population of over 2 million inhabitants, including the area in which GLOBE participants resided. Information on vital status of the patients was obtained from the population registries network, which provides virtually complete coverage of all deceased citizens of The Netherlands. Follow-up was complete for cancer patients until 31 December 2009. Non-cancer patients who moved out of the area were lost to follow-up. Data on cause of death were not available in this study.

Questionnaire information from respondents and cancer registry records were linked in a two-step procedure. First, a combination of the respondent's sex, date of birth and the first two characters of his or her last name at birth were used as a linking key. In a second step, uncertain matches were checked by visual inspection of the Eindhoven Cancer Registry, using identifiable data (such as initials, full last names and address). We included patients diagnosed from 1991 to 2008. Patients who indicated in the questionnaire that they had suffered from 'malignant disease or cancer' in the past were excluded from the present study $(n=70$, mainly cancers of the breast, colon and lung and basal cell carcinomas), as patients could have changed to a more healthy lifestyle in response to their disease. Survival rates are only shown if at least five patients were at risk of dying per subgroup for any given time since diagnosis. We studied four common cancers: patients with colon and non-small cell lung cancer, male subjects with prostate cancer, and female subjects with breast cancer. In the analyses of all cancers combined, basal cell carcinomas were excluded since these have very low lethality. Furthermore, in case a patient had more than one tumour, we only included the first cancer.

\section{Educational level}

Educational level was indicated by the highest attained level of education with students classified according to their current training, using a closed question in the baseline questionnaire. Four different groups were created: (1) primary school only; (2) lower vocational school and lower secondary school; (3) intermediate vocational school and intermediate/higher secondary school; and (4) higher vocational school and university. In The Netherlands, educational level is recognised as a good indicator of SEP. ${ }^{24}$ The highly educated group was used as the reference group.

\section{Behavioural variables}

Self-reported current smoking behaviour was categorised into four groups: never, former smoker, current smoker and unknown. On the basis of questions on the average number of days per week that individuals used alcohol and the average number of glasses consumed per day, individuals were categorised into five groups for alcohol consumption: total abstainers; light; moderate; excessive; and unknown drinkers (for details $\operatorname{see}^{25}$ ). Leisure physical activity was calculated from the number of hours spent on gardening, cycling, walking and physical exercise (none or little; moderate; much; unknown, for details $\left.\operatorname{see}^{26}\right)$.

\section{Survival analyses}

Crude survival analyses were performed using the KaplanMeier method, and comparisons between groups assessed by the log rank test. Cox proportional regression analyses were performed to assess the effects of comorbidities and behavioural variables on risk of death. We first adjusted for age categories (0-59, 60-69 and 70 years and older), period of diagnosis (1991-1996, 1997-2002 and 2003-2008) and stage at diagnosis. Subsequently we adjusted for presence of comorbidities, categorised into: $0 ; 1 ; 2$ or more; unknown. We additionally added alcohol, physical activity and smoking, resulting in the final model. The comparisons of models with different covariates were tested with the likelihood ratio test.

\section{RESULTS}

Between 1991 and 2008, 2576 first primary tumours were diagnosed within the GLOBE population of 18973 individuals (table 1). The percentage of patients with a low educational level varied considerably per tumour localisation; $41 \%$ of male small cell lung cancer patients and $39 \%$ of female patients with non-melanoma skin cancer or with unknown primary localisation only attended primary school, compared with $19 \%$ and $18 \%$ of the male and female melanoma patients. Survival was best in patients with a high educational level, in both male and female subjects (figure 1). Crude 5-year survival for all cancers combined (ie, all cancers as presented in table 1) was $49 \%$ in male subjects with high educational level compared with $32 \%$ in low education (log rank: $\mathrm{p}<0.0001$ ), and $65 \%$ and $49 \%$ in female subjects $(p=0.0001)$, respectively (see figure 1$)$.

Subsequent analyses were only performed on patients with known educational level and with breast (female subjects only, $n=356)$, colon $(n=226)$, prostate $(n=271)$ or non-small cell lung cancer $(n=274)$. These 1127 tumours were present in 1096 patients. In prostate cancer, patients with low educational level had poorer survival (log rank: $p=0.0002)$, while crude survival from colon cancer and non-small cell lung cancer was the lowest in highly educated patients (figure 1, $\mathrm{p}=0.2$ and 0.5 , respectively). Breast cancer survival was best in highly educated women (5-year survival $87 \%)$ and poorest in low educated women $(69 \%, \mathrm{p}=0.2)$.

No consistent socioeconomic patterns were present in mean age or stage distribution of the cancer patients (data not shown). 
Table 1 Percentage of patients by tumour site (10 most common and basal cell carcinoma) and educational level, patients in the longitudinal GLOBE study, Eindhoven, The Netherlands, diagnosed 1991-2008

\begin{tabular}{|c|c|c|c|c|c|c|}
\hline & \multirow[b]{2}{*}{$\begin{array}{l}\text { Total } \\
\mathrm{N}\end{array}$} & \multicolumn{5}{|c|}{ Educational level } \\
\hline & & $\begin{array}{l}1 . \\
\text { Low } \\
\%\end{array}$ & $\begin{array}{l}2 . \\
\%\end{array}$ & $\begin{array}{l}3 . \\
\%\end{array}$ & $\begin{array}{l}4 . \\
\text { High } \\
\%\end{array}$ & $\begin{array}{l}\text { Other/ } \\
\text { unknown } \\
\%\end{array}$ \\
\hline \multicolumn{7}{|l|}{ Males } \\
\hline $\begin{array}{l}\text { Oesophagus (including cardia } \\
\text { stomach) }\end{array}$ & 46 & 20 & 48 & 11 & 17 & 4 \\
\hline Colon & 127 & 20 & 29 & 28 & 19 & 3 \\
\hline Rectum & 62 & 27 & 34 & 16 & 19 & 3 \\
\hline Non-small cell lung cancer & 225 & 35 & 30 & 20 & 8 & 6 \\
\hline Small cell lung cancer & 69 & 41 & 36 & 10 & 13 & 0 \\
\hline Skin, melanoma & 52 & 19 & 25 & 21 & 35 & 0 \\
\hline Skin, non-melanoma $\left(\mathrm{SCC}^{*}\right)$ & 69 & 28 & 29 & 19 & 20 & 4 \\
\hline Prostate & 286 & 25 & 26 & 21 & 23 & 5 \\
\hline Urinary bladder & 107 & 32 & 22 & 24 & 20 & 3 \\
\hline Primary localisation unknown & 46 & 33 & 22 & 22 & 17 & 7 \\
\hline $\begin{array}{l}\text { Total (excluding basal cell } \\
\text { carcinoma) }\end{array}$ & 1435 & 27 & 30 & 21 & 18 & 4 \\
\hline Skin, basal cell carcinoma & 186 & 25 & 28 & 19 & 23 & 5 \\
\hline \multicolumn{7}{|l|}{ Females } \\
\hline Colon & 115 & 32 & 40 & 10 & 7 & 10 \\
\hline Rectum & 40 & 35 & 38 & 20 & 3 & 5 \\
\hline Pancreas & 26 & 35 & 54 & 12 & 0 & 0 \\
\hline Non-small cell lung cancer & 65 & 34 & 49 & 12 & 0 & 5 \\
\hline Skin, melanoma & 38 & 18 & 58 & 18 & 5 & 0 \\
\hline Skin, non-melanoma (SCC) & 44 & 39 & 48 & 7 & 2 & 5 \\
\hline Breast & 371 & 26 & 51 & 15 & 5 & 4 \\
\hline Corpus uteri & 60 & 37 & 48 & 7 & 8 & 0 \\
\hline Ovary & 39 & 23 & 44 & 18 & 13 & 3 \\
\hline Primary localisation unknown & 41 & 39 & 37 & 5 & 10 & 10 \\
\hline $\begin{array}{l}\text { Total (excluding basal cell } \\
\text { carcinoma) }\end{array}$ & 1141 & 31 & 47 & 13 & 5 & 5 \\
\hline Skin, basal cell carcinoma & 161 & 25 & 45 & 21 & 2 & 7 \\
\hline
\end{tabular}

The prevalence of comorbidities was slightly higher among low educated cancer patients (table 2). Furthermore, among the low educated patients, a higher proportion smoked and did not drink any alcohol. Levels of physical activity were the highest among the highest educated. Crude survival from colon, prostate and breast cancer was better among patients with no or, in case of prostate and breast cancer, one comorbidity than with two or more comorbidities, with $11 \%$ higher 3 -year survival in colon cancer patients with no comorbidities compared with patients with two or more comorbidities ( $\mathrm{p}$ value log rank test: $0.0015), 21 \%$ in prostate $(p=0.0004)$ and $8 \%$ in breast cancer $(p=0.0012)$. Furthermore, crude survival was better in prostate and breast cancer patients with high compared with low levels of physical activity ( $31 \%$ higher in prostate $(\mathrm{p}=0.0167), 2 \%$ in breast $(\mathrm{p}=0.0454))($ table 3$)$. Among prostate and breast cancer patients, survival was better for those with light or excessive alcohol consumption than for total abstainers or moderate consumers, although none of these associations were statistically significant.

In multivariable models adjusting for age, year of diagnosis and stage at diagnosis, risk of death in prostate cancer patients was higher for those with low compared with high education, although with wide CIs ( $\mathrm{HR}_{\text {low_vs_high_educated }} 2.9$ (95\% CI 1.7 to 5.1) see table 4). Associations of education with risk of death among breast, colon and non-small cell lung cancer patients were inconsistent and non-significant after adjustment for age, year of diagnosis and stage at diagnosis.

In multivariable models for prostate cancer as presented in table 5 , poor survival was predicted by presence of comorbidities $\left(\mathrm{HR}_{2}\right.$ or more vs no comorbidities: 2.6 (1.5 to 4.4)), low levels of physical activity $\left(\mathrm{HR}_{\mathrm{no}}\right.$ /ittle vs moderate physical activity: 2.0 (1.2 to $3.4))$ and being a current smoker ( $\mathrm{HR}_{\text {current }}$ vs never smokers: 2.6 $(1.0$ to 6.8$)$ ). The increased hazard of death in low educated prostate cancer patients compared with the highly educated patients (model A, HR low vs high educated: 2.9 (1.7 to 5.1), table 4) hardly changed by inclusion of comorbidities $\left(\mathrm{HR}_{\text {low_vs_high_educated: }} 2.7\right.$ (1.6 to 4.8), table 5), lifestyle behaviours ( $\mathrm{HR}_{\text {low_vs_high_educated: }} 3.0(1.6$ to 5.6$\left.)\right)$ or both in the model ( $\mathrm{HR}_{\text {low }}$ vs high educated: 3.1 (1.6 to 5.8$)$ ). In contrast to lifestyle behaviours, adding comorbidity to the model leads to a significantly better fit of the data (likelihood ratio test model A + comorbidity compared with model A: $\mathrm{p}<0.01$ ).

Survival of colon, breast and non-small cell lung cancers was not associated with educational level and associations remained of similar magnitude after inclusion of comorbidities and/or lifestyle behaviours in the multivariable models (see online supplementary tables S1, S2, S3A, S3B and S4).

\section{DISCUSSION}

In this study, we investigated educational differences in cancer survival and the contribution of comorbidity and lifestyle to survival. In all cancers combined and prostate cancer patients separately, those with high education had the best survival. In contrast, risks of death were inconsistently or not related to education in colon, breast and non-small cell lung cancer. Although comorbidity and lifestyle behaviours predicted death in prostate cancer patients, these could not explain the increased risk of death in low educated prostate cancer patients.

Our results confirm previous studies that also pointed to better survival for patients with high SEP for prostate cancer, while our findings are not in line with associations previously reported for breast, colon and lung (which will be discussed later). ${ }^{4} 511 \quad 12 \quad 14 \quad 27$ Not surprisingly, the difference between high and low SEP in survival was limited for lung cancer, which is rather lethal and the effects of comorbidities and lifestyle are expected to be minor. Contrasting our expectations, crude survival was lower in highly educated non-small cell lung cancer patients than in low educated, although not significantly. These probably relate to differences in comorbidities and age, since hazards of death were not significantly related to education in the multivariable analyses.

The reasons for socioeconomic inequalities in cancer survival are not exactly known yet, but differences in stage at diagnosis, treatment and lifestyle-related factors such as physical activity, obesity and dietary patterns have been proposed. Some previous studies took into account stage at diagnosis, which was reported not to fully explain better survival in high SEP patients with prostate (depending on age), breast (only in screen-detected tumours) and in some studies on colorectal cancer. ${ }^{4} 111427$ We also observed a strong significant effect of stage on survival, but it did not explain all of the educational inequalities in prostate cancer survival. In addition, excluding stage from the age and year adjusted model only little increased the HR for low compared with high educated patients 
Males, all cancers

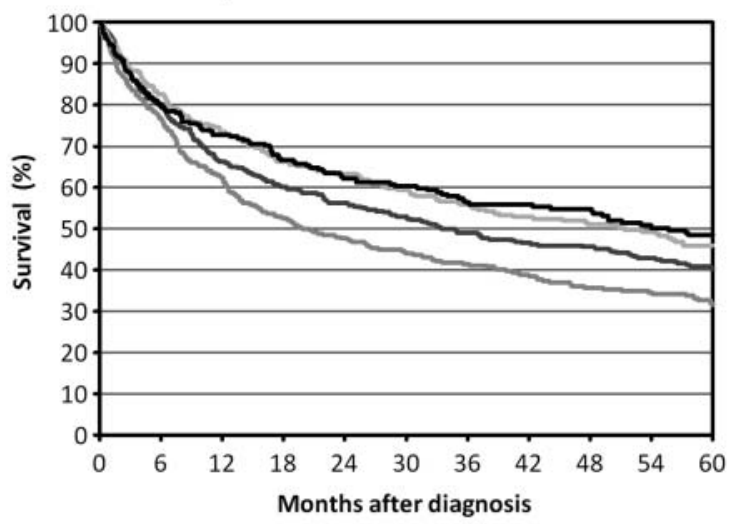

Colon cancer

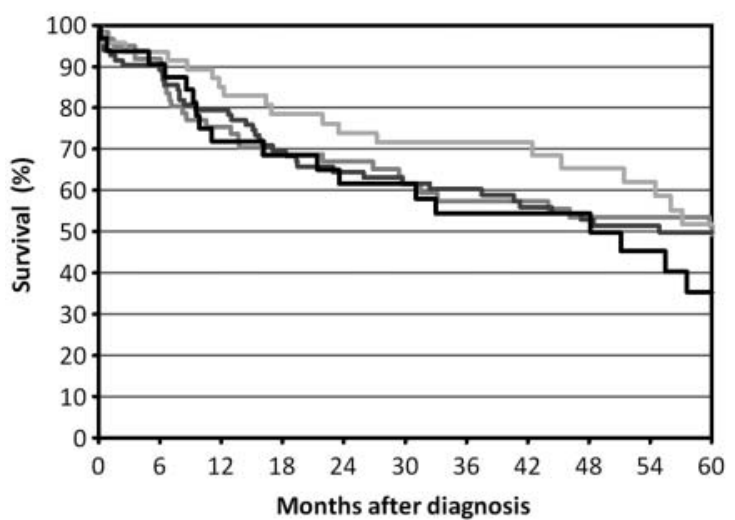

Males, prostate cancer

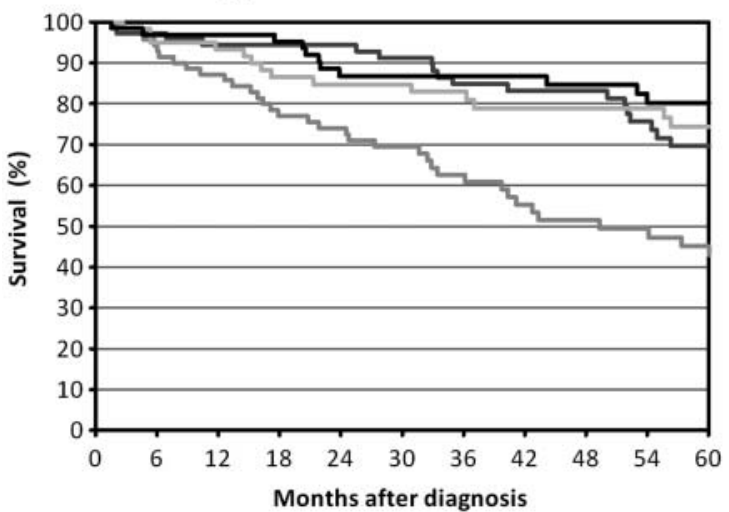

Females, all cancers

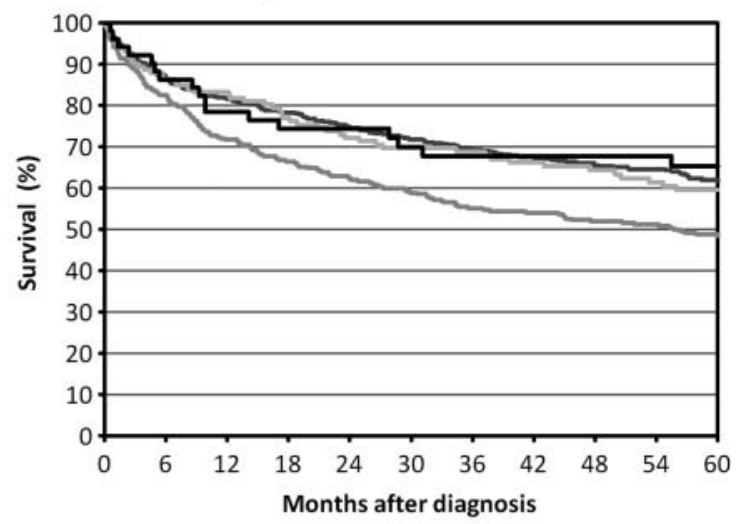

Non-small lung cancer

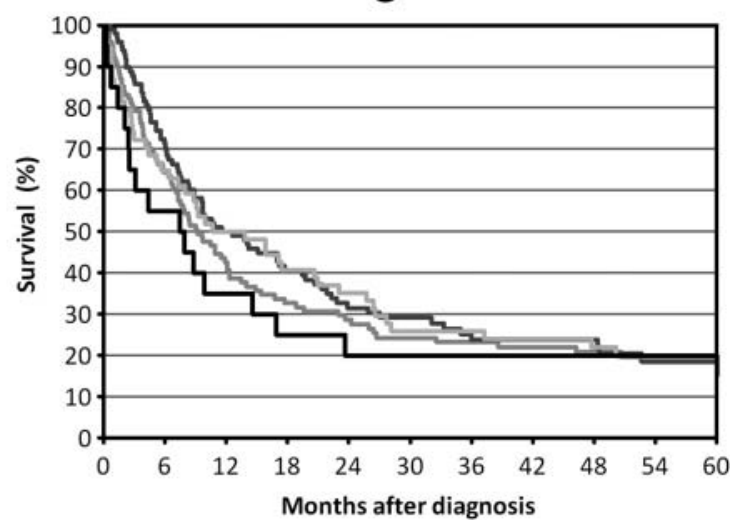

Females, breast cancer

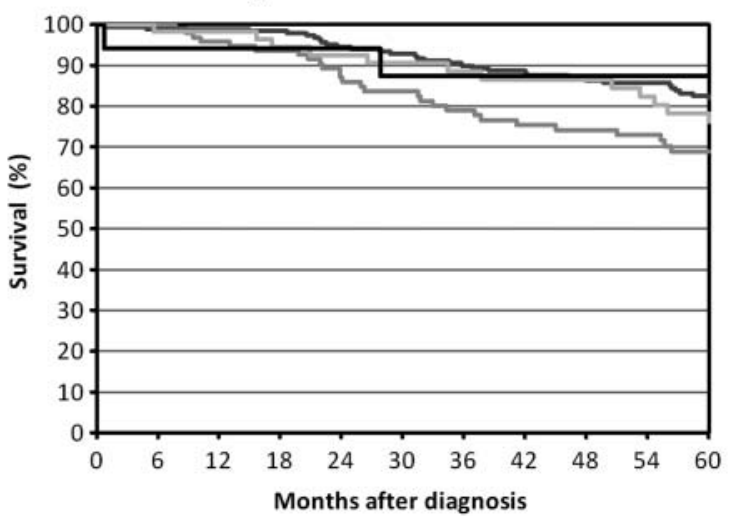

-1 low education -2 .

- 3. - 4. high education

Figure 1 Crude survival from cancer by tumour site and sex, according to educational level, patients in the longitudinal GLOBE study, Eindhoven, The Netherlands, diagnosed 1991-2008.

(data not shown). Also unsurprisingly, age was strongly related to survival.

In our analyses we furthermore adjusted for presence of comorbidities at diagnosis, and investigated the additional effects of alcohol consumption, physical activity and smoking on educational inequalities in cancer survival. We assumed that by adjusting for comorbidity we also adjusted partly for lifestyle. Comparing the models with comorbidity, behaviour and the final model shows that associations of lifestyle hardly changed by inclusion of comorbidity and vice versa (see online supplementary tables S1, S2, S3A, S3B and S4, likelihood ratio test for all comparisons not significant). This may suggest that comorbidities reflect high-risk behaviours well.

Previously we have shown that comorbidities explained some of the socioeconomic variation in breast, colorectal and prostate cancer survival. $^{13} 1427$ Although comorbidity was reported to be a significant prognostic factor in cancer, ${ }^{28}$ it did not explain the educational difference in prostate cancer survival in our study. We expect this to result from the rather weak association between education and comorbidities.

Furthermore, differences in treatment between socioeconomic groups may contribute to the socioeconomic inequalities in 
Table 2 Distribution of comorbidity at diagnosis and behaviours at baseline (1991) by educational level in the longitudinal GLOBE study, Eindhoven, The Netherlands, including patients with prostate, non-small cell lung, colon and breast cancer, diagnosed 1991-2008

\begin{tabular}{|c|c|c|c|c|c|}
\hline \multirow[b]{2}{*}{ Number of tumours } & \multicolumn{4}{|c|}{ Educational level } & \multirow[b]{2}{*}{ p Value* } \\
\hline & $\begin{array}{l}\text { 1. Low } \\
330(\%)\end{array}$ & $\begin{array}{l}2 . \\
443(\%)\end{array}$ & $\begin{array}{l}3 . \\
219(\%)\end{array}$ & $\begin{array}{l}\text { 4. High } \\
135(\%)\end{array}$ & \\
\hline \multicolumn{6}{|l|}{ Comorbidities } \\
\hline None & 27 & 43 & 35 & 39 & 0.0006 \\
\hline 1 & 26 & 26 & 29 & 27 & \\
\hline 2 or more & 35 & 21 & 23 & 23 & \\
\hline Unknown & 12 & 10 & 13 & 11 & \\
\hline \multicolumn{6}{|l|}{ Smoking } \\
\hline Never & 25 & 24 & 18 & 13 & $<0.0001$ \\
\hline Former & 25 & 33 & 39 & 55 & \\
\hline Current & 46 & 41 & 41 & 33 & \\
\hline Unknown & 5 & 2 & 2 & 0 & \\
\hline \multicolumn{6}{|l|}{ Alcohol } \\
\hline Total abstainers & 37 & 21 & 11 & 8 & $<0.0001$ \\
\hline Light & 33 & 45 & 39 & 39 & \\
\hline Moderate & 12 & 19 & 32 & 42 & \\
\hline Excessive & 8 & 9 & 14 & 7 & \\
\hline Unknown & 11 & 6 & 4 & 4 & \\
\hline \multicolumn{6}{|l|}{ Physical activity } \\
\hline None/little & 21 & 19 & 15 & 11 & $<0.0001$ \\
\hline Moderate & 58 & 56 & 49 & 50 & \\
\hline Much & 14 & 23 & 32 & 37 & \\
\hline Unknown & 8 & 2 & 4 & 2 & \\
\hline
\end{tabular}

cancer survival. Unfortunately, small numbers of patients receiving each therapeutic option hampered inclusion in multivariable analyses. However, since we adjusted for clinical stage in our analyses, and since treatment is related to stage (as we expect patients with more advanced stages of cancer to receive other types of treatment than those with less severe stages), additional adjustment for treatment is not likely to substantially change our results.

Few studies investigated the role of lifestyle in socioeconomic inequalities in cancer survival. A Danish study showed that comorbidity, and to a lesser extent lifestyle, were influencing the socioeconomic variation in colorectal cancer survival, while factors related to disease or treatment were not contributing to the variation. ${ }^{29}$ Also smoking status prior cancer diagnosis was an important predictive factor for socioeconomic variation in cancer survival in Norwegian women, whereas in breast cancer no association with smoking status, alcohol consumption, stage or comorbidity was found. ${ }^{30}$ In men smoking and alcohol consumption did not explain socioeconomic variation in Swedish overall cancer survival. ${ }^{15}$ In New Zealand, socioeconomic variation in colorectal cancer survival could not be explained by smoking status, alcohol intake and physical activity. ${ }^{16}$ Previously the role of alcohol was suggested to substantially influence socioeconomic inequalities in male cancer mortality (being the product of incidence and survival) in some, but not other European countries. ${ }^{31}$ The Netherlands was not taken into account.

Other factors that could contribute to the better survival in highly educated cancer patients are healthier lifestyle in general (other than we could measure). Furthermore, those with high
Table 3 Crude survival according to number of comorbidities at diagnosis and behaviours at baseline (1991) per tumour site in the longitudinal GLOBE study, Eindhoven, The Netherlands

\begin{tabular}{|c|c|c|c|c|}
\hline & Colon & $\begin{array}{l}\text { Non-small } \\
\text { cell lung }\end{array}$ & Prostate & Breast \\
\hline \multirow[t]{2}{*}{ Mean age at diagnosis } & 70.4 & 66.4 & 70.1 & 63.5 \\
\hline & $\begin{array}{l}\text { 3-year } \\
\text { survival } \\
(\%)\end{array}$ & $\begin{array}{l}\text { 1-year } \\
\text { survival } \\
(\%)\end{array}$ & $\begin{array}{l}\text { 3-year } \\
\text { survival } \\
(\%)\end{array}$ & $\begin{array}{l}\text { 3-year } \\
\text { survival } \\
(\%)\end{array}$ \\
\hline \multicolumn{5}{|l|}{ Comorbidities at diagnosis } \\
\hline None & 69 & 41 & 85 & 88 \\
\hline 1 & 53 & 49 & 84 & 86 \\
\hline 2 or more & 58 & 45 & 64 & 80 \\
\hline Unknown & 68 & 55 & 83 & 87 \\
\hline \multicolumn{5}{|l|}{ Smoking } \\
\hline Never & 62 & * & 81 & 87 \\
\hline Former & 63 & 52 & 80 & 84 \\
\hline Current & 58 & 45 & 76 & 87 \\
\hline Unknown & * & * & 86 & 92 \\
\hline \multicolumn{5}{|l|}{ Alcohol } \\
\hline Total abstainers & 64 & 45 & 69 & 83 \\
\hline Light & 67 & 45 & 82 & 90 \\
\hline Moderate & 54 & 38 & 79 & 80 \\
\hline Excessive & 55 & 57 & 90 & 94 \\
\hline Unknown & 50 & 63 & 67 & 88 \\
\hline \multicolumn{5}{|l|}{ Physical activity } \\
\hline None/little & 80 & 47 & 57 & 88 \\
\hline Moderate & 57 & 48 & 82 & 85 \\
\hline Much & 57 & 38 & 88 & 90 \\
\hline Unknown & 56 & 50 & * & 64 \\
\hline
\end{tabular}

SEP have generally better capacity to obtain, process and understand health information and services (the so-called 'health literacy'). ${ }^{3}{ }^{32}$ These socioeconomic differences in health literacy could have contributed to better cancer survival among highly educated prostate cancer patients.

For prostate cancer we stratified the analyses according to tumour stage to unravel possible screening effects. Overall, results were similar to the total group of prostate cancer patients. Compared with those with advanced stage, effects of smoking and physical activity were stronger in those with localised disease (see online supplementary table S3A and S3B). Presence of comorbidities strongly affected risk of death in those with advanced disease $(\geq 2$ compared with no comorbidities: HR 4.8 (95\% CI 1.7 to 13.8$)$ ).

Prostate cancer survival might have also been influenced by the increased use of prostate specific antigen (PSA) tests, which occurred mainly from 2000 onwards. ${ }^{33-35}$ It has been reported that PSA testing occurs more often in male subjects with high compared with low SEP. ${ }^{36}$ However, by adjusting for tumour stage at diagnosis we aimed at taking at least part of these socioeconomic differences in staging into account.

Relatively small studies like GLOBE take a long time to answer questions on socioeconomic inequalities in survival of specific types of cancer. A systematic approach to study these inequalities is important, and cancer registries could play an important role in these studies. 
Table 4 Multivariable risk of death according to tumour site for cancer patients in the longitudinal GLOBE study, Eindhoven, The Netherlands, diagnosed 1991-2008

\begin{tabular}{|c|c|c|c|c|c|c|c|c|}
\hline & \multicolumn{2}{|c|}{ Colon } & \multicolumn{2}{|c|}{ Non-small cell lung } & \multicolumn{2}{|c|}{ Prostate } & \multicolumn{2}{|c|}{ Breast } \\
\hline & HR & $95 \% \mathrm{Cl}$ & $\mathrm{HR}$ & $95 \% \mathrm{Cl}$ & HR & $95 \% \mathrm{Cl}$ & HR & $95 \% \mathrm{Cl}$ \\
\hline \multicolumn{9}{|l|}{ Age } \\
\hline $0-59$ & 1.0 & & 1.0 & & 1.0 & & 1.0 & \\
\hline $60-69$ & 1.7 & 0.8 to 3.7 & 2.1 & 1.4 to 3.1 & 2.0 & 0.7 to 5.2 & 1.3 & 0.8 to 2.1 \\
\hline $70+$ & 1.9 & 0.9 to 4.1 & 2.6 & 1.7 to 3.9 & 5.0 & 1.6 to 12.7 & 2.5 & 1.5 to 4.0 \\
\hline \multicolumn{9}{|l|}{ Sex } \\
\hline Female & 1.0 & 0.6 to 1.4 & 1.0 & 0.7 to 1.4 & - & & - & \\
\hline Male & 1.0 & & 1.0 & & & & & \\
\hline \multicolumn{9}{|c|}{ Year of diagnosis } \\
\hline 1991-1996 & 1.0 & 0.6 to 1.7 & 1.5 & 1.0 to 2.2 & 1.0 & 0.0 to 1.9 & 0.8 & 0.4 to 1.4 \\
\hline 1997-2002 & 1.4 & 0.9 to 2.2 & 1.5 & 1.1 to 2.1 & 1.3 & 0.2 to 2.1 & 1.1 & 0.6 to 1.9 \\
\hline $2003-2008$ & 1.0 & & 1.0 & & 1.0 & & 1.0 & \\
\hline \multicolumn{9}{|l|}{ Stage } \\
\hline 1 & 1.0 & & 1.0 & & 1.0 & & 1.0 & \\
\hline 2 & 1.0 & 0.5 to 1.9 & 2.7 & 1.4 to 5.5 & 1.0 & 0.0 to 2.0 & 2.0 & 1.3 to 3.1 \\
\hline 3 & 1.9 & 1.0 to 3.6 & 2.9 & 2.0 to 4.3 & 1.2 & 0.2 to 3.0 & 2.6 & 1.4 to 4.9 \\
\hline 4 & 8.4 & 4.4 to 16.1 & 5.9 & 3.8 to 9.0 & 4.0 & 1.4 to 7.8 & 10.8 & 5.0 to 23.2 \\
\hline Unknown & 20.7 & 7.7 to 56.1 & 1.3 & 0.8 to 2.1 & 4.4 & 1.5 to 11.3 & 1.1 & 0.2 to 8.4 \\
\hline \multicolumn{9}{|l|}{ Education } \\
\hline 1. Low & 1.1 & 0.6 to 1.9 & 0.8 & 0.5 to 1.3 & 2.9 & 1.7 to 5.1 & 1.5 & 0.5 to 4.4 \\
\hline 2. & 0.7 & 0.4 to 1.2 & 0.7 & 0.4 to 1.2 & 1.5 & 0.4 to 2.6 & 1.3 & 0.4 to 3.5 \\
\hline 3. & 0.7 & 0.3 to 1.2 & 0.8 & 0.5 to 1.5 & 1.6 & 0.5 to 3.0 & 1.4 & 0.5 to 4.3 \\
\hline 4. High & 1.0 & & 1.0 & & 1.0 & & 1.0 & \\
\hline
\end{tabular}

Values in bold are significant. Models are adjusted for all variables listed.

Our study findings might be influenced by several methodological limitations. We have excluded subjects with prevalent cancer at baseline (ie, 1991) in order to eliminate possible selection effects. The validity of the self-reported prevalence of cancer in the study population that filled in the 1991 questionnaire was checked, and some under-reporting was found among those with a lower educational level. ${ }^{37}$ Furthermore, we assumed that lifestyle prior to cancer diagnosis was indicative to lifestyle after diagnosis. However, this can be debated as the experience of cancer diagnosis and treatment may serve as a critical cue for an individual to make positive health behaviour changes. ${ }^{38}$ Also the small number of patients within each group, which is reflected by the wide CIs, is a serious weakness of our study. This may explain the rather unusual results for colon, breast and non-small lung cancer survival, which was not associated with education. Unfortunately, we were only able to calculate overall survival, since no SEP-specific life tables were available to estimate cancer specific survival according to SEP.

Reporting of smoking habits, alcohol consumption and physical activity may be inaccurate and is often understated or overstated in case of physical activity, although a recent study reported that this was not true for nicotine consumption. ${ }^{39-41}$ Reporting on these items may differ across the SEP groups, thereby introducing differential bias. This may dilute the effect of lifestyle and may (partly) explain why lifestyle hardly affected the educational differences in cancer survival.

A disadvantage of using education is that it better reflects SEP in some age cohorts than in others. ${ }^{42}$ Those born before 1950 may not have attained the educational level that could be expected based on their potential abilities. This effect is probably stronger for women. The effect of possible misclassification of SEP by using educational level may explain why our results are not in accordance with previous studies on SEP and cancer survival and on the prevalence of comorbidities and SEP, which explained part of the inequalities in cancer survival. ${ }^{13} 14$ Besides, it may also explain the rather uncommon finding of relatively few highly educated women with breast cancer. However, we previously reported no consistent pattern for breast cancer incidence with SEP for all ages combined, but high incidence rates in elderly women with low SEP. ${ }^{7}$ Because a large proportion of the breast cancer patients in our study is relatively old, it may explain higher breast cancer incidence rates in women with low education.

Nevertheless, comparison of the educational level with fiscal data on household income and value of housing ${ }^{43}$ shows a fair correlation.

A strength of this study is that the follow-up of the original sample on vital status has been nearly complete $(99.8 \%)$. Additionally, the completeness of the Eindhoven Cancer Registry is expected to be at least $95 \% ;{ }^{44}$ thus, only few new cancer cases diagnosed within the registration area would not be included in the cancer registry. Furthermore, the area covered by the Eindhoven Cancer Registry is much larger than the area covered by the GLOBE study, so participants who moved outside the area of the GLOBE study, but still within the area of the Eindhoven Cancer Registry, could also be included in the present study. Those moving outside the GLOBE study area were in a previous study found to be mainly highly educated individuals with few comorbidities and high levels of physical activity, which might have influenced our results. However, these were mostly young individuals who have a low chance of developing cancer. ${ }^{45}$ Finally, the two-step linkage procedure 
Table 5 Multivariable risk of death for prostate cancer patients in the longitudinal GLOBE study, Eindhoven, The Netherlands, diagnosed 1991-2008

\begin{tabular}{|c|c|c|c|c|c|c|}
\hline & \multicolumn{2}{|c|}{ Model A+comorbidity } & \multicolumn{2}{|c|}{$\begin{array}{l}\text { Model A+lifestyle } \\
\text { behaviours }\end{array}$} & \multicolumn{2}{|c|}{$\begin{array}{l}\text { Model A+comorbidity } \\
\text { +lifestyle behaviours }\end{array}$} \\
\hline & HR & $95 \% \mathrm{Cl}$ & HR & $95 \% \mathrm{Cl}$ & HR & $95 \% \mathrm{Cl}$ \\
\hline \multicolumn{7}{|l|}{ Age } \\
\hline $0-59$ & 1.0 & & 1.0 & & 1.0 & \\
\hline $60-69$ & 1.8 & 0.7 to 4.7 & 2.4 & 0.9 to 6.4 & 2.1 & 0.8 to 5.7 \\
\hline $70+$ & 3.9 & 1.5 to 10.1 & 5.8 & 2.2 to 15.5 & 4.7 & 1.7 to 12.6 \\
\hline \multicolumn{7}{|l|}{ Year of diagnosis } \\
\hline 1991-1996 & 1.4 & 0.7 to 2.6 & 1.0 & 0.5 to 1.7 & 1.3 & 0.7 to 2.4 \\
\hline $1997-2002$ & 1.3 & 0.8 to 2.2 & 1.2 & 0.7 to 2.1 & 1.3 & 0.8 to 2.2 \\
\hline $2003-2008$ & 1.0 & & 1.0 & & 1.0 & \\
\hline \multicolumn{7}{|l|}{ Stage } \\
\hline 1 & 1.0 & & 1.0 & & 1.0 & \\
\hline 2 & 1.4 & 0.7 to 2.8 & 0.9 & 0.5 to 1.9 & 1.3 & 0.6 to 2.6 \\
\hline 3 & 1.6 & 0.6 to 4.2 & 0.9 & 0.4 to 2.3 & 1.3 & 0.5 to 3.3 \\
\hline 4 & 6.0 & 2.9 to 12.1 & 3.7 & 1.9 to 7.3 & 5.4 & 2.6 to 11.1 \\
\hline Unknown & 5.9 & 2.3 to 15.3 & 4.8 & 1.8 to 12.6 & 6.5 & 2.5 to 17.4 \\
\hline \multicolumn{7}{|l|}{ Education } \\
\hline 1. Low & 2.7 & 1.6 to 4.8 & 3.0 & 1.6 to 5.6 & 3.1 & 1.6 to 5.8 \\
\hline 2. & 1.4 & 0.8 to 2.5 & 1.4 & 0.8 to 2.5 & 1.4 & 0.8 to 2.6 \\
\hline 3. & 1.6 & 0.9 to 2.9 & 1.6 & 0.9 to 2.9 & 1.5 & 0.8 to 2.8 \\
\hline 4. High & 1.0 & & 1.0 & & 1.0 & \\
\hline \multicolumn{7}{|l|}{ Comorbidities } \\
\hline 0 & 1.0 & & & & 1.0 & \\
\hline 1 & 1.5 & 0.9 to 2.5 & & & 1.8 & 1.0 to 3.0 \\
\hline 2 or more & 2.6 & 1.5 to 4.4 & & & 3.0 & 1.7 to 5.1 \\
\hline Unknown & 1.2 & 0.6 to 2.5 & & & 1.8 & 0.8 to 3.7 \\
\hline \multicolumn{7}{|l|}{ Alcohol } \\
\hline Abstainer & & & 0.9 & 0.5 to 2.0 & 0.9 & 0.4 to 1.9 \\
\hline Light & & & 1.0 & 0.6 to 1.7 & 1.1 & 0.6 to 1.7 \\
\hline Moderate & & & 1.0 & & 1.0 & \\
\hline Excessive & & & 1.3 & 0.6 to 2.8 & 1.3 & 0.6 to 2.8 \\
\hline Unknown & & & 1.6 & 0.6 to 4.0 & 1.7 & 0.7 to 4.4 \\
\hline \multicolumn{7}{|l|}{ Physical activity } \\
\hline No/little & & & 2.0 & 1.2 to 3.4 & 1.9 & 1.1 to 3.4 \\
\hline Moderate & & & 1.0 & & 1.0 & \\
\hline Much & & & 1.0 & 0.6 to 1.5 & 1.1 & 0.7 to 1.8 \\
\hline Unknown & & & 2.5 & 1.0 to 6.4 & 3.2 & 1.3 to 8.4 \\
\hline \multicolumn{7}{|l|}{ Smoking } \\
\hline Never & & & 1.0 & & 1.0 & \\
\hline Former & & & 2.5 & 1.0 to 6.7 & 2.5 & 0.9 to 6.7 \\
\hline Current & & & 2.6 & 1.0 to 6.8 & 3.0 & 1.1 to 7.8 \\
\hline Unknown & & & 0.8 & 0.2 to 4.2 & 0.6 & 0.1 to 3.1 \\
\hline Likelihood ratio test compared with model $\mathrm{A}$ & $p<0.01$ & & $p>0.05$ & & $p<0.005$ & \\
\hline
\end{tabular}

Values in bold are significant. Models are adjusted for all variables listed.

ascertained the appropriate identification of cancer patients within the GLOBE cohort. This makes it unlikely that the results have been biased by incompleteness of data on cancer diagnosis.

To conclude, highly educated prostate cancer patients had reduced risks of death. Although presence of comorbidities, physical activity levels and smoking status affected survival from prostate cancer, these did not explain educational inequalities in prostate survival. The role of other factors, such as capacity to obtain, process and understand health information and services, and access to healthcare, needs to be explored.

\section{What is already known on this subject?}

- Cancer survival is generally better for patients with high socioeconomic position, which has been ascribed partly to lower prevalence of other chronic diseases (comorbidities) and generally healthier lifestyle behaviours in patients with high socioeconomic position. The combined effect of comorbidities and lifestyle and cancer survival according to socioeconomic position has not been studied before. 


\section{What does this study add?}

- Educational inequalities in survival were observed in prostate cancer, while no or inconsistent associations were found for breast, colon and non-small cell lung cancer. Although those with comorbidities, with no or little physical activity and current smokers had increased risk of death, these did not explain educational inequalities in prostate cancer survival.

Acknowledgements The GLOBE study is carried out by the Department of Public Health of the Erasmus University Medical Centre in Rotterdam, in collaboration with the Public Health Services of the city of Eindhoven and region Southeast Brabant. The study is supported by grants of the Ministry of Public health, Welfare and Sport and the Health Research and Development Council.

Contributors The authors made substantial contributions to this study: MJA: analysis and interpretation of data, drafting of manuscript, and critical revision of the manuscript. CBMK: acquisition of data, interpretation of data, drafting of the manuscript and critical revision of the manuscript. WJL: interpretation of data, drafting of the manuscript and critical revision of the manuscript. JWWC: interpretation of data and critical revision of the manuscript. JPM: study conception and design, acquisition of data and critical revision of the manuscript. FJL: study conception and design, acquisition of data, interpretation of data, drafting of the manuscript and critical revision of the manuscript.

Funding Name of Funder: Ministry of Public health, Welfare and Sport; Health Research and Development Council.

\section{Competing interests None.}

Ethics approval The use of personal data in the GLOBE study is in compliance with the Dutch Personal Data Protection Act and the Municipal Database Act, and has been registered with the Dutch Data Protection Authority (number 1248943).

Provenance and peer review Not commissioned; externally peer reviewed.

This is an open-access article distributed under the terms of the Creative Commons Attribution Non-commercial License, which permits use, distribution, and reproduction in any medium, provided the original work is properly cited, the use is non commercial and is otherwise in compliance with the license. See: http:/l creativecommons.org/licenses/by-nc/2.0/ and http://creativecommons.org/licenses/bync/2.0/legalcode.

\section{REFERENCES}

1 Faggiano F, Partanen T, Kogevinas M, et al. Socioeconomic differences in cancer incidence and mortality. IARC Sci Publ 1997;138:65-176.

2 Menvielle G, Leclerc A, Chastang JF, et al. Changes in socioeconomic inequalities in cancer mortality rates among French men between 1968 and 1996. Am J Public Health 2007;97:2082-7.

3 Mackenbach JP, Stirbu I, Roskam AJ, et al. Socioeconomic inequalities in health in 22 European countries. N Engl J Med 2008;358:2468-81.

4 Aarts MJ, Lemmens VEPP, Louwman WJ, et al. Socioeconomic status and changing inequalities in colorectal cancer? A review of the associations with risk, treatment and outcome. Eur J Cancer 2010;46:2681-95.

5 Dalton SO, Schuz J, Engholm G, et al. Social inequality in incidence of and survival from cancer in a population-based study in Denmark, 1994-2003: summary of findings. Eur J Cancer 2008;44:2074-85.

6 National Cancer Intelligence Network. Cancer incidence by deprivation. England, 1995-2004. London, 2009.

7 Aarts MJ, van der Aa MA, Coebergh JW, et al. Reduction of socioeconomic inequality in cancer incidence in the South of the Netherlands during 1996-2008. Eur J Cancer 2010;46:2633-46.

8 Louwman WJ, van Lenthe FJ, Coebergh JW, et al. Behaviour partly explains educational differences in cancer incidence in the south-eastern Netherlands: the longitudinal GLOBE study. Eur J Cancer Prev 2004;13:119-25.

9 Parkin DM, Boyd L, Walker LC. The fraction of cancer attributable to lifestyle and environmental factors in the UK in 2010. Summary and conclusions. Br J Cancer 2011;105:S77-81.

10 Schrijvers CT, Coebergh JW, van der Heijden LH, et al. Socioeconomic variation in cancer survival in the southeastern Netherlands, 1980-1989. Cancer 1995;75:2946-53.

11 Woods LM, Rachet B, Coleman MP. Origins of socio-economic inequalities in cancer survival: a review. Ann Oncol 2006;17:5-19.

12 Kogevinas M, Porta M. Socioeconomic differences in cancer survival: a review of the evidence. IARC Sci Pub/ 1997:177-206.
13 Louwman WJ, Aarts MJ, Houterman S, et al. A 50\% higher prevalence of life-shortening chronic conditions among cancer patients with low socioeconomic status. Br J Cancer 2010;103:1742-8.

14 Aarts MJ, Koldewijn EL, Poortmans PMP, et al. Impact of socioeconomic status on prostate cancer treatment and survival in the Southern Netherlands. in press, Urology.

15 Rosengren A, Wilhelmsen L. Cancer incidence, mortality from cancer and survival in men of different occupational classes. Eur J Epidemiol 2004;19:533-40.

16 Kelsall HL, Baglietto L, Muller D, et al. The effect of socioeconomic status on survival from colorectal cancer in the Melbourne Collaborative Cohort Study. Soc Sci Med 2009;68:290-7.

17 Mackenbach JP. Socioeconomic inequalities in health in The Netherlands: impact of a five year research programme. BMJ 1994;309:1487-91.

18 van Lenthe FJ, Schrijvers CT, Droomers $M$, et al. Investigating explanations of socio-economic inequalities in health: the Dutch GLOBE study. Eur J Public Health 2004; 14:63-70.

19 Parkin DM, Bray F, Ferlay J, et al. Global cancer statistics, 2002. CA Cancer J Clin 2005:55:74-108

20 Hermanek P, Sobin L International Union Against Cancer (UICC): TNM Classification of Malignant Tumors. Berlin, Heidelberg, New York: Springer-Verlag, 1987.

21 Sobin L, Wittekind C. UICC International Union against Cancer. TNM Classification of malignant tumours. 5th edn. Geneva, Switzerland: Wiley-Liss, 1997.

22 Sobin L, Wittekind C UICC International Union against Cancer. TNM Classification of malignant tumours. 6th edn. Geneva, Switzerland: Wiley-Liss, 2002.

23 Charlson ME, Pompei $\mathrm{P}$, Ales $\mathrm{KL}$, et al. A new method of classifying prognostic comorbidity in longitudinal studies: development and validation. J Chron Dis 1987:40:373-83.

24 van Berkel-van Schaik AB, Tax B. Naar een standaardoperationalisatie van sociaal-economische status voor epidemiologisch en sociaal-medisch onderzoek. (Towards a standard operationalisation of socioeconomic status for epidemiological and sociomedical research). Rijswijk: Ministerie van WCC, 1990.

25 van Lenthe FJ, Avendano M, van Beeck EF, et al. Childhood and adulthood socioeconomic position and the hospital-based incidence of hip fractures after 13 years of follow-up: the role of health behaviours. J Epidemiol Community Health 2011;65:980-5.

26 Slingerland AS, van Lenthe FJ, Jukema JW, et al. Aging, retirement, and changes in physical activity: prospective cohort findings from the GLOBE study. Am J Epidemiol 2007; 165:1356-63.

27 Aarts MJ, Voogd AC, Duijm LEM, et al. Socioeconomic inequalities in attending the mass screening for breast cancer in the south of the Netherlands-associations with stage at diagnosis and survival. Breast Cancer Res Treat 2011;128:517-25.

28 Janssen-Heijnen ML, Houterman S, Lemmens VE, et al. Prognostic impact of increasing age and co-morbidity in cancer patients: a population-based approach. Crit Rev Oncol Hematol 2005;55:231-40.

29 Frederiksen $\mathrm{BL}$, Osler $\mathrm{M}$, Harling $\mathrm{H}$, et al. Do patient characteristics, disease, or treatment explain social inequality in survival from colorectal cancer? Soc Sci Med 2009;69:1107-15.

30 Braaten $T$, Weiderpass $E$, Kumle $M$, et al. Explaining the socioeconomic variation in cancer risk in the Norwegian Women and Cancer Study. Cancer Epidemiol Biomarkers Prev 2005;14:2591-7.

31 Menvielle G, Kunst AE, Stirbu I, et al. Socioeconomic inequalities in alcohol related cancer mortality among men: to what extent do they differ between Western European populations? Int J Cancer 2007;121:649-55.

32 Smith SG, Wolf MS, von Wagner C. Socioeconomic status, statistical confidence, and patient-provider communication: an analysis of the Health Information National Trends Survey (HINTS 2007). J Health Commun 2010;15(Suppl 3):169-85.

33 Cremers RGHM, Karim-Kos HE, Houterman S, et al. Prostate cancer: trends in incidence, survival and mortality in the Netherlands, 1989-2006. Eur J Cancer 2010;46:2077-87.

34 Post PN, Kil PJ, Crommelin MA, et al. Trends in incidence and mortality rates for prostate cancer before and after prostate-specific antigen introduction. A registry-based study in southeastern Netherlands, 1971-1995. Eur J Cancer 1998;34:705-9.

35 Statistics Netherlands. Gezondheid, leefstijl, zorggebruik; t/m 2009 (in Dutch) 2010. http://statline.cbs.nl/StatWeb/publication/? $\mathrm{DM}=\mathrm{SLNL} \& \mathrm{PA}=03799 \& \mathrm{D} 1=291 \& \mathrm{D} 2=0-17 \& \mathrm{D} 3=0 \& \mathrm{D} 4=\mathrm{a} \& \mathrm{VW}=\mathrm{T}$ Statistics Netherlands.

36 Fitzpatrick P, Corcoran N, Fitzpatrick JM. Prostate cancer: how aware is the public? Br J Urol 1998;82:43-8.

37 Schrijvers CT, Stronks K, van de Mheen DH, et al. Validation of cancer prevalence data from a postal survey by comparison with cancer registry records. Am J Epidemiol 1994;139:408-14.

38 Patterson RE, Neuhouser ML, Hedderson MM, et al. Changes in diet, physical activity, and supplement use among adults diagnosed with cancer. J Am Diet Assoc 2003;103:323-8.

39 Adams SA, Matthews CE, Ebbeling CB, et al. The effect of social desirability and social approval on self-reports of physical activity. Am J Epidemiol 2005:161:389-98. 
40 Hebert JR, Clemow L, Pbert L, et al. Social desirability bias in dietary self-report may compromise the validity of dietary intake measures. Int J Epidemiol 1995;24:389-98.

41 Yeager DS, Krosnick JA. The validity of self-reported nicotine product use in the 2001-2008 National Health and Nutrition Examination Survey. Med Care 2010:48:1128-32.

42 Berkman LF, Macintyre $S$. The measurement of social class in health studies: old measures and new formulations. IARC Sci Publ 1997;138:51-64.
43 Duin van C, Keij I. Sociaal-economische status indicator op postcodeniveau. Maandstatistiek van de bevolking 2002;50:32-5.

44 Schouten LJ, Hoppener P, van den Brandt PA, et al. Completeness of cancer registration in Limburg, The Netherlands. Int J Epidemiol 1993;22:369-76.

45 van Lenthe FJ, Martikainen P, Mackenbach JP. Neighbourhood inequalities in health and health-related behaviour: results of selective migration? Health Place 2007:13:123-37. 